Check for updates

Cite this: RSC Adv., 2019, 9, 20226

\title{
A review of the applications of ion floatation: wastewater treatment, mineral beneficiation and hydrometallurgy
}

\author{
Luping Chang, (D) ${ }^{a}$ Yijun Cao, ${ }^{* a b}$ Guixia Fan, ${ }^{a}$ Chao Li ${ }^{b}$ and Weijun Peng (iD) *a
}

Ion flotation was originally used for pre-concentrating precious metals from dilute solutions. To date, it has attracted widespread attention in many fields due to its low energy requirements, simplicity, rapid operation, small space requirements, suitability for a variety of target ions at various levels, small volume of sludge, low residual concentration, and low operating cost. This review focuses on the applications of ion flotation in wastewater treatment, mineral beneficiation, such as rare precious metal recovery, and hydrometallurgy, such as pre-concentrating of rare earth elements and selective separation of multicomponent ions. The outlook of ion flotation is also discussed.

Received 17th April 2019

Accepted 30th May 2019

DOI: $10.1039 / c 9 r a 02905 b$

rsc.li/rsc-advances

of the target ions to form a surfactant complex and then collecting the ions by passing gas bubbles through the solution. A small volume of a hydrophobic product that contains concentrated target ions is formed at the top of a flotation machine and recycled, as clearly depicted in Fig. 1.,5 $^{4,5}$ As a promising separation process, much attention has been paid to ion flotation due to its low energy requirements, simplicity, rapid operation, small space requirements, suitability for a variety of target ions at various levels, small volume of sludge, low residual concentration, relatively low cost, etc. ${ }^{6-9}$

In the original studies, ion flotation was mostly used for preconcentrating precious metals from dilute solutions. To date, the ion flotation method has also been applied for wastewater and water treatment, ${ }^{10-12}$ recovery of precious metals, ${ }^{13,14}$ pre-

Henan, 450001, PR China.E-mail:yijuncao@126.com; pwj@zzu.edu.cn

${ }^{b}$ Henan Province Industrial Technology Research Institute of Resources and Materials, Zhengzhou University, Zhengzhou, Henan, 450001, PR China

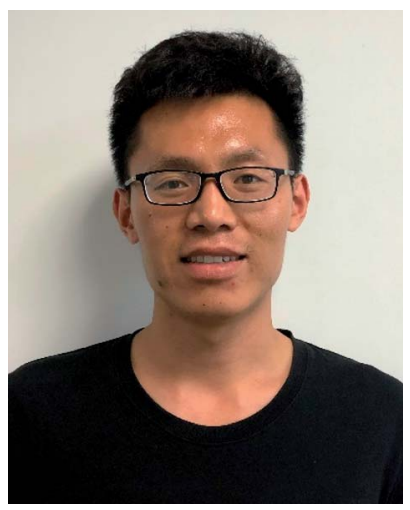

Luping Chang received his Bachelor's Degree from Shandong University of Technology; he received his Master's Degree from Sinosteel Maanshan Mining Research Institute in 2014. Recently, he began PhD studies at Zhengzhou University. Currently, he is engaged in research on the treatment of heavy metal wastewater from mines.

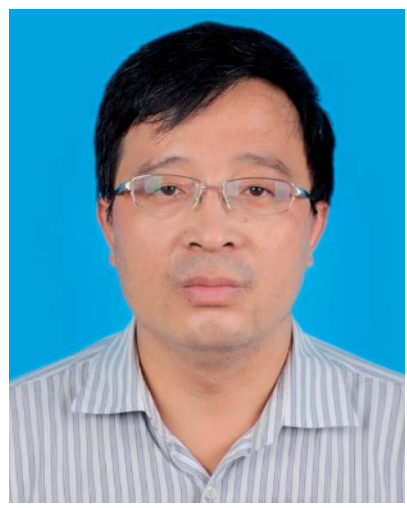

Yijun Cao is the Deputy Director of the Chinese National Engineering Research Center of Coal Preparation and Purification at the China University of Mining and Technology (CUMT), Xuzhou, China. He obtained his Doctoral degree in mineral processing at Kunming University of Science and Technology, Kunming, China. He was named a "Changjiang Scholar" by the Ministry of Education of China in 2016. Currently, his research mainly focuses on ultra-fine mineral separation, flotation equipment development, and treatment of mine and chemical wastewater. 
concentrating of rare earth elements, ${ }^{\mathbf{1 5 , 1 6}}$ and selective separation of multicomponent ions. ${ }^{17,18}$

The current state of the application of ion flotation is therefore reviewed in this paper. Basically, this review focuses on the application of ion flotation in wastewater treatment, mineral beneficiation, such as rare precious metal recovery, and hydrometallurgy, such as pre-concentrating of rare earth elements and selective separation of multicomponent ions; the intent of this review is to provide ideas and inspiration to spark rapid development of the application of ion flotation.

\section{Wastewater treatment}

The rapid development of industry and the increasing productivity of many industrial branches have resulted in the pollution of ground water sources; thus, people worldwide face the problems of lack of fresh water together with the spread of various diseases due to organic and inorganic contaminants. ${ }^{\mathbf{1 9}}$ Sustainable development of wastewater is especially stressed because wastewater is a renewable resource from which water can be recovered for reuse..$^{\mathbf{2 0}-22}$ Numerous methods have been developed to remove contaminants from aqueous solutions, such as chemical precipitation, oxidation or reduction, adsorption, coagulation/flocculation, filtration, ion-exchange, electrochemical treatment, reverse osmosis, membrane

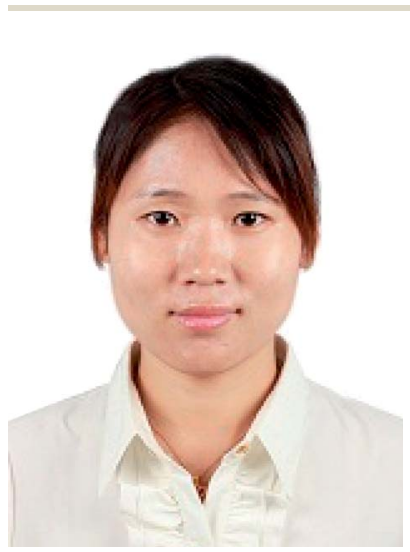

Dr Guixia-Fan obtained her PhD degree in Professor Jiong-tian Liu's group at the China University of Mining and Technology, China. Her research fields include the theory, technics and equipment of mineral processing; surface and interface technology; and mineral materials.

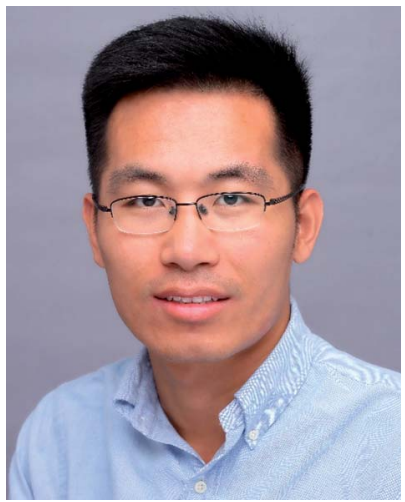

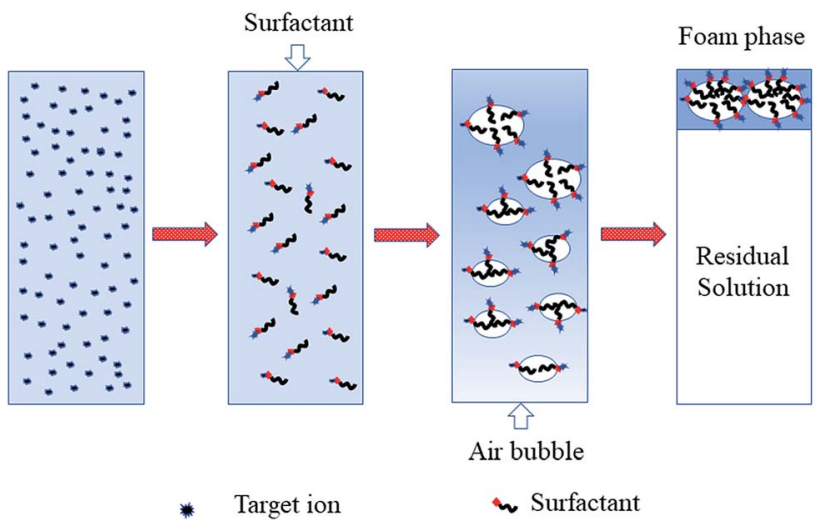

Fig. 1 Schematic of the overall process of ion flotation.

technology, evaporation and electroflotation., ${ }^{\mathbf{5 3 - 2 5}}$ This may be due to the fact that metal ions can enter water bodies and soil, accumulate in animals and plants through the food chain, and eventually accumulate in the human body, seriously endangering human health and life due to their non-degradability, mobility and persistence. ${ }^{26}$ However, these removal methods have many disadvantages, such as high cost, generation of large amounts of sludge, high reagent or energy requirements, time consumption, incomplete removal of target ions, production of secondary wastes and difficulty of treatment of large volumes of wastewater. ${ }^{27-29}$ Accordingly, ion flotation has been evaluated as a good alternative treatment process for wastewater treatment due to its low energy requirements, simplicity, rapid operation, small space requirements, etc.

Lead is a persistent and toxic contaminant that emanates from acid batteries, painting, printing, ceramic and glass manufacturing, and production of lead additives for gasoline. Long-term exposure can lead to anaemia, cancer, kidney disease, metal retardation, etc. ${ }^{\mathbf{3 0 - 3 2}}$ Craioveanu et al. conducted much research on $\mathrm{Pb}$ (II) removal; they noted that high removal efficiency $(R \%=99.93)$ could be obtained under optimum conditions using a naturally occurring compound (caffeic acid) as a collector. The removal mechanism is based on the fact that caffeic acid contains numerous complexing polar groups that

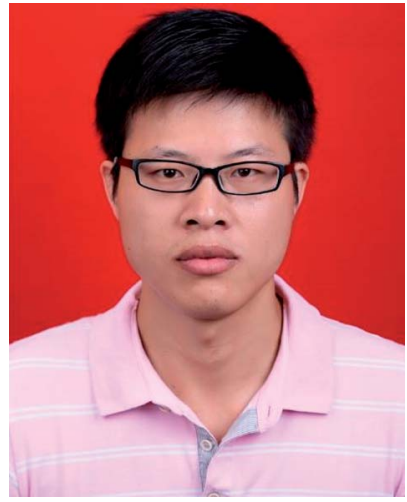

Weijun Peng is an Associate Professor of metallurgical engineering at Zhengzhou University. He obtained his PhD in 2017 from Wuhan University of Technology. Dr Peng's research interests are mine and metallurgical wastewater treatment, non-metallic ore beneficiation and materialization, and electrode materials for supercapacitors and electrical adsorption. 
can actively react with metallic ions. ${ }^{33}$ Similar studies were carried out by Peng et al.; they found that the removal of $\mathrm{Pb}$ (II) could be greater than $99 \%$ and the turbidity of the residual solution could decrease to 1.4 NTU by ion flotation under the optimum operation parameters when using graphene oxide (GO) as the collector (as shown in Fig. 2a). In addition, the GO could be reused after desorption, and the $\mathrm{Pb}$ (II) removal remained as high as $84.9 \%$ in the sixth regeneration (as shown in Fig. 2b). ${ }^{34}$ Additionally, they noted that GO was much more efficient than other collectors when used in $\mathrm{Pb}$ (II) removal experiments due to the fact that nanoscale GO possesses great numbers of hydroxyl and carboxyl groups that mainly participate in bonding with $\mathrm{Pb}$ (II) (as shown in Fig. 2c). ${ }^{23,35}$

In addition, cadmium may cause destructive trauma to human organs, such as the kidneys, liver, and lungs, and to cardiovascular, immune and reproductive systems. Gratifyingly, in a study by Salmani et al., more than $92.1 \%$ of Cd(II) could be efficiently removed from simulated water via ion flotation under the optimum conditions. ${ }^{36}$

Subsequently, more research on metal ion removal via ion flotation was undertaken by many researchers. They found that ion flotation could not only work on single metal ions but also on multicomponent metal ions. Mahmoud et al. carried out an investigation of the simultaneous removal of cationic ion nickel(II) and anion ion chromium(vi) from simulated wastewaters and aqueous solutions. The results indicated that removals of more than $99.5 \%$ were obtained for both nickel(II) and chromium(vi) in a single step via flotation even when the target ions were at high concentrations and the residual concentrations were all below their permissible limits in potable water. ${ }^{37} \mathrm{Ni}$ (II) and $\mathrm{Zn(II)}$ ions could be removed simultaneously by ion flotation according to the research of Hoseinian et al. The removal rates of $\mathrm{Ni}$ (II) and $\mathrm{Zn}$ (II) ions were $88 \%$ and $92 \%$, respectively, when SDS was used as the collector and Dowfroth 250 as the frother under the effective parameters investigated by experimental design performed by DX7 software and evaluated in a mechanical flotation cell (as shown in Fig. 3). ${ }^{38}$ Almost $100 \%$ removal of $\mathrm{Cd}(\mathrm{II})$ and $\mathrm{Zn}$ (II) at pH 5 and $60 \%$ to $70 \% \mathrm{Sr}$ (II) removal at $\mathrm{pH} 7$ to 9 were achieved by Eivazihollagh et al. via ion flotation when 2-dodecyldiethylenetriamine pentaacetic acid (C12-DTPA) served as the collector in combination with two foaming agents: dodecyl trimethyl
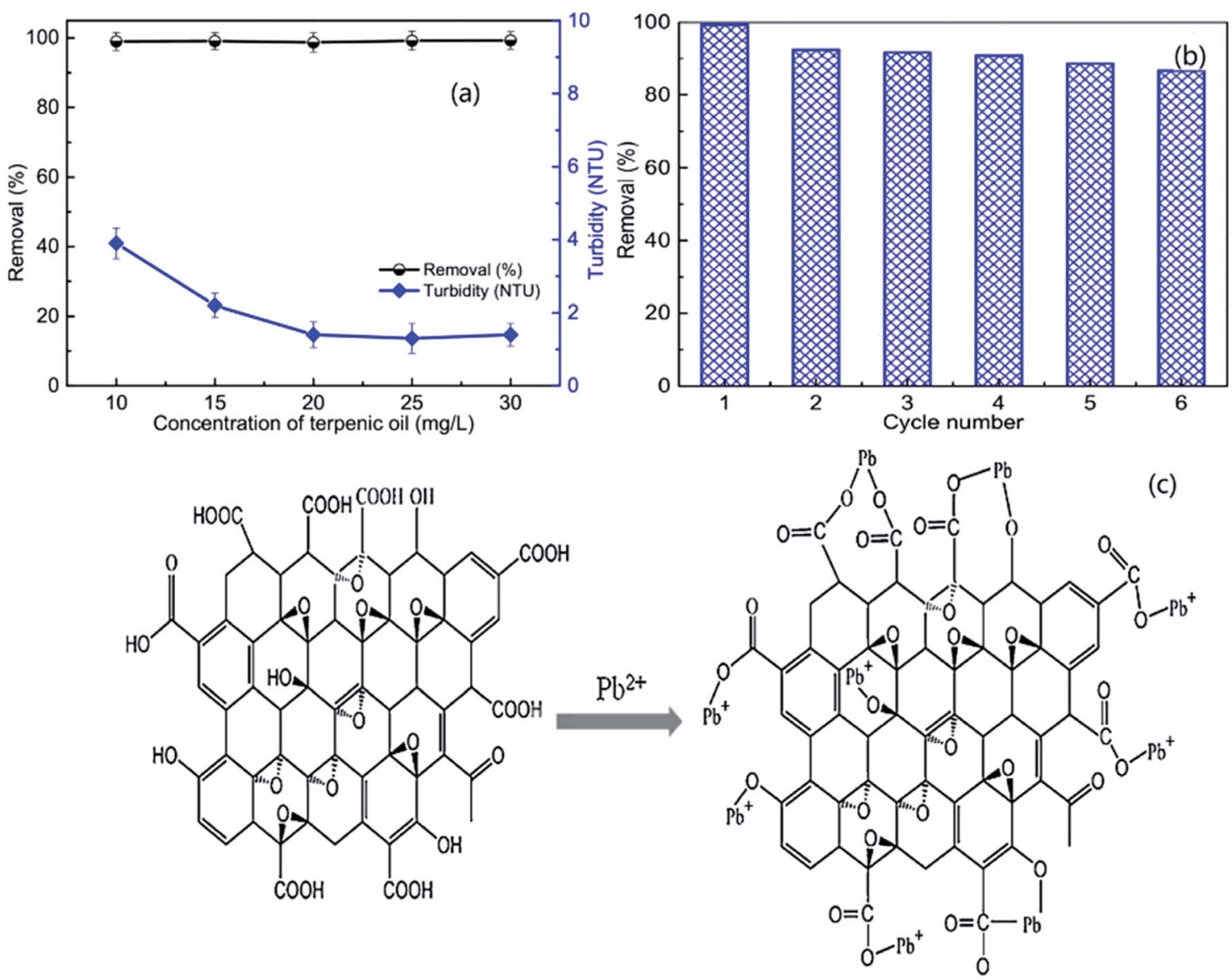

Fig. 2 Effects of the dosage of frother (terpenic oil) on the removal of $\mathrm{Pb}(॥)$ and the turbidity of the residual solution (a); removal of $\mathrm{Pb}(॥)$ as a function of cycle number (b). Schematic of the mechanism of the adsorption of $\mathrm{Pb}(\mathrm{\prime l})$ on the surface of $\mathrm{GO}$ (c). Adapted from ref. 34 and 35 with permission from Elsevier. Copyright 2018 and 2016. Adapted from W. Peng, G. Han, Y. Cao, K. Sun and S. Song, Efficiently removing Pb(॥) from wastewater by graphene oxide using foam flotation, Colloids Surf., A, 556, 266-272, Copyright (2018), with permission from Elsevier. Reprinted from W. Peng, H. Li, Y. Liu and S. Song, Comparison of $\mathrm{Pb}(\Perp)$ adsorption onto graphene oxide prepared from natural graphites: diagramming the $\mathrm{Pb}(\mathrm{II})$ adsorption sites, Appl. Surf. Sci., 364, 620-627, Copyright (2016), with permission from Elsevier. 


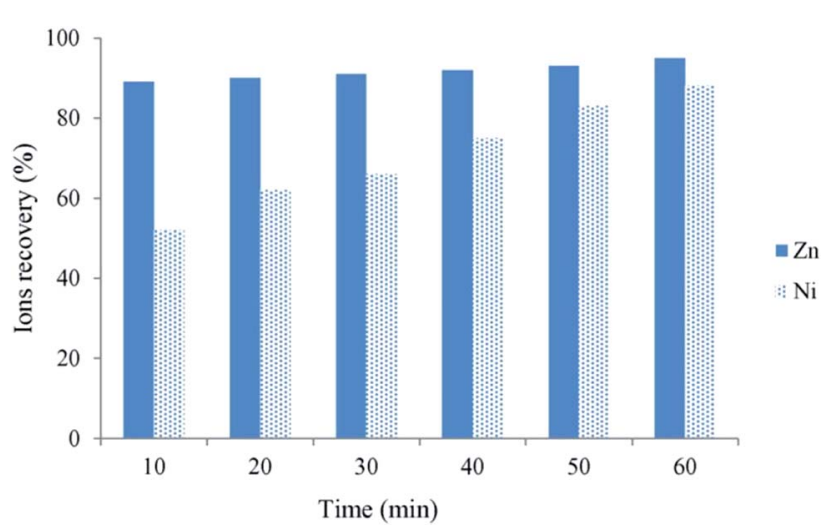

Fig. $3 \mathrm{Ni}(I)$ and $\mathrm{Zn}(॥)$ ion recoveries as a function of flotation time. (SDS $=300$ ppm, Dowfroth $250=90$ ppm, $Z n(॥)=\mathrm{Ni}(॥)=10 \mathrm{ppm}, \mathrm{pH}$ 3 and agitating speed $=1000 \mathrm{rpm})$. Reproduced from ref. 38 with permission from Elsevier, Copyright 2015. Reprinted from F. S. Hoseinian, M. Irannajad and A J. Nooshabadi, Ion flotation for removal of $\mathrm{Ni}(॥)$ and $\mathrm{Zn}(॥)$ ions from wastewaters, Int. J. Miner. Process., 143, 131-137, Copyright (2015), with permission from Elsevier.

ammonium chloride (DoTAC) and dimethyl dodecyl amine- $N$ oxide (DDAO).$^{39}$ Moreover, Yenidünya studied the removal of $\mathrm{Zn}$ (II), $\mathrm{Mn}$ (II) and $\mathrm{Cu}$ (II) from aqueous solution by ion flotation with sodium dodecyl sulphate in combination with some auxiliary ligands (malic acid, maleic acid and EDTA). He found that the maximum removal rates for $\mathrm{Zn}$ (II), $\mathrm{Mn}$ (II) and $\mathrm{Cu}$ (II) were $90.5 \%, 99.8 \%$ and $73.4 \%$, respectively, within $60 \mathrm{~min}$ when the molar ratio between the metal and sodium dodecyl sulphate was $1: 5$. Moreover, by adding auxiliary ligands (malic acid and maleic acid), the recovery efficiencies for all metal ions increased and the flotation times decreased to 40, 20 and $40 \mathrm{~min}$ for $\mathrm{Zn}$ (II), $\mathrm{Mn}$ (II) and $\mathrm{Cu}(\mathrm{II})$, respectively, when the molar ratio of metal : sodium dodecyl sulphate : auxiliary ligand was $1: 5: 5{ }^{40}$ It is evident that ion flotation has a high removal capacity for various metal ions and that the type and dosage of surfactant, solution $\mathrm{pH}$, flotation time, etc. all play important roles in the process. The mechanisms for the removal of metal ions are mainly attributed to electrostatic attraction, ion exchange and surface complexation between the surfactant and target ions; these ions are then separated from the solution by attachment to gas bubbles passing through the solutions.

In addition to heavy metal ions, ion flotation is also commonly used for removing organic and biological pollutants such as oil, triazine herbicides, perfluorooctane sulfonate (PFOS) and perfluorooctanoate, Rhodamine 6G and sulfonylurea herbicides from wastewater or aqueous solution. ${ }^{41-47}$

Lignin removal research was conducted by Wang et al. through ion flotation using cetyl dimethyl benzyl ammonium as the surfactant. They found that a fraction of more than 0.95 could be removed by continuous ion flotation under the optimum operational conditions. ${ }^{48}$ The residual concentration of Direct Red could be lowered to below 0.5 ppm after 3 minutes of treatment by ion flotation when Choi et al. used sodium lauryl sulfate as both collector and frother. ${ }^{49}$ Rhodamine B (RB) and thoron (TH) are widely used for analytical and biological staining purposes and may deleteriously affect water. Removals exceeding $99.5 \%$ and $99.9 \%$ could be achieved for RB and $\mathrm{TH}$, respectively, when Shakir et al. adopted the anionic surfactant sodium lauryl sulfate (NaLS) and the cationic surfactant cetyltrimethylammonium bromide (CTAB) as collectors. ${ }^{50}$ More than $96 \%$ of cationic dyes could be removed and the enrichment factors in the foam were about 6 under the optimum conditions when Groß et al. used two commercially available biopolymers as alternatives to classical surfactants for dye removal via ion flotation (as shown in Fig. 4). However, for anionic dyes, a further cationic surfactant, DTAB, should be added; the removal can thus be increased from $5 \%$ to $70 \%{ }^{51} \mathrm{Hu}$ et al. also used ion flotation technology to remove methylene blue using commercial hydrophobic silica nanoparticles (SNP) (200.0 \pm $10.0 \mathrm{~nm}$ average particle size) as a collector without using any surfactants. Removal efficiencies of methylene blue and SNPs and volume ratios of $91.1 \pm 4.6 \%, 93.9 \pm 4.7 \%$, and $10.5 \pm 0.5 \%$ could be respectively obtained at pH 9.0, a SNP concentration of
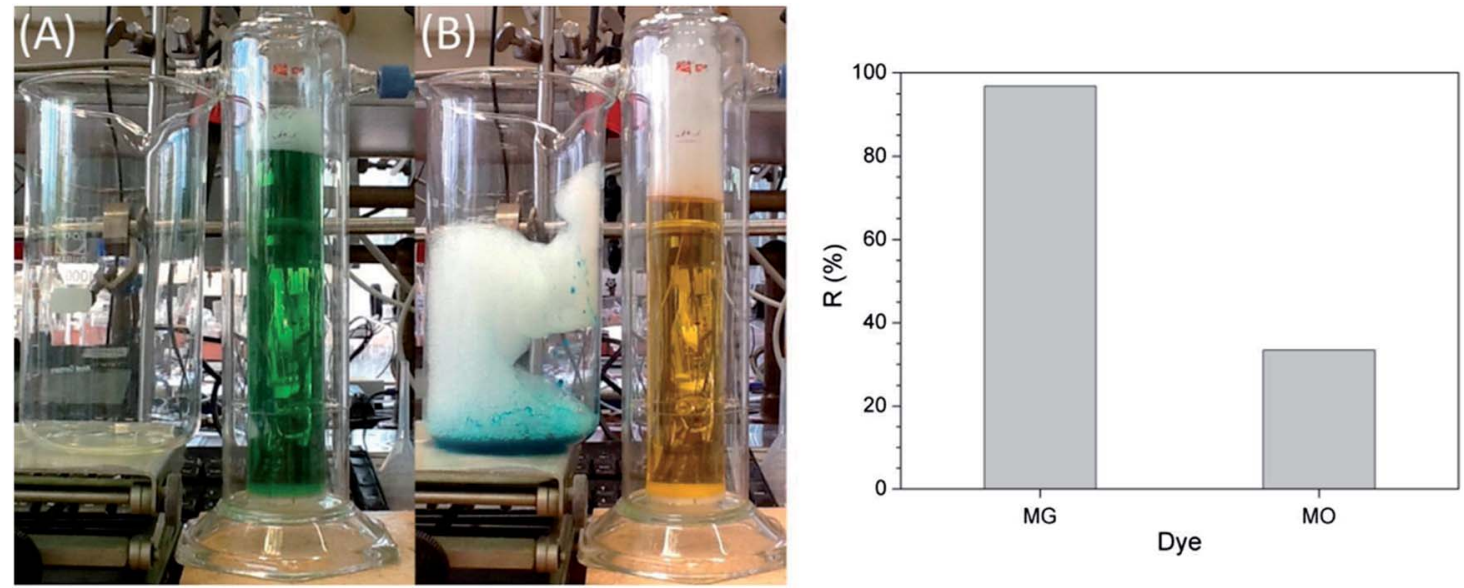

Fig. 4 Separation of malachite green (MG) and methyl orange (MO) by flotation with HeSat as the collector. Conditions: $C_{\mathrm{HeSat}}=0.5 \mathrm{~g} \mathrm{~L}{ }^{-1}, \mathrm{C}_{\mathrm{MG}}=$

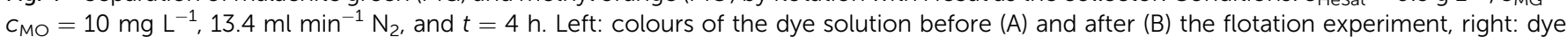
removal efficiencies. Reproduced from ref. 51 with permission from Elsevier, Copyright 2017. 
$600 \mathrm{mg} \mathrm{L}^{-1}$, an anhydrous ethanol dosage of $8 \mathrm{ml}$ and a flotation column height of $600 \mathrm{~mm}$. In addition, methylene could be effectively separated from methylene blue-adsorbed SNPs with ethanol at $\mathrm{pH} 2.0$ for reuse at least five times (as shown in Fig. 5 and Table 1). ${ }^{52}$ Tetracyclines are broad-spectrum antibiotics that are most commonly prescribed for human therapy; meanwhile, they are also commonly used in livestock farming. Therefore, they are one of the most commonly detected antibiotics in surface water resources discharged from agriculture wastewater and medical wastewater, and they should be removed as much as possible before discharge. ${ }^{53,54}$ Saitoh et al. carried out a large number of experiments, and they noted that almost complete removal ( $>99 \%$ ) of tetracycline antibiotics could be obtained with the combined use of $20 \mathrm{mg} \mathrm{L}^{-1}$ of an anionic surfactant, sodium dodecyl sulfate (SDS), $6.5 \mathrm{mg} \mathrm{L}^{-1}$ of a cationic polyelectrolyte, poly (allylamine hydrochloride) $[\mathrm{PAH}]$, and $1 \mathrm{mg} \mathrm{L}^{-1} \mathrm{Al}(\mathrm{III})$. The remaining concentration of SDS was lower than that permitted by Japanese water regulations. Additionally, this process was used to remove other tetracycline and fluoroquinolone antibiotics as well as different acidic and basic pharmaceuticals, even in five minutes. ${ }^{55}$ Boron and its compounds are important materials in the fields of medicine, material science, the chemical industry, the nuclear industry and agriculture; additionally, boron is an essential

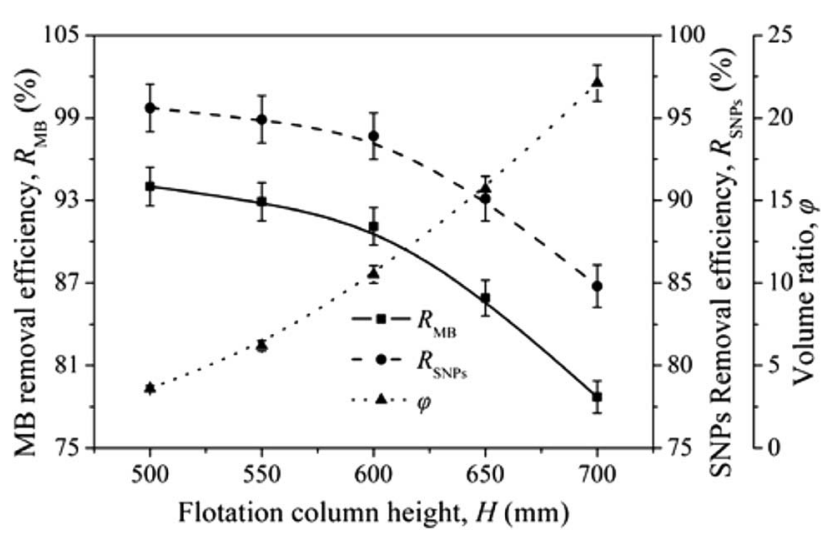

Fig. 5 Effects of flotation column height on $R_{\mathrm{MB}}, R_{\mathrm{SNPS}}$ and $\varphi$. Reproduced from ref. 52 with permission from Springer, Copyright 2017. Reprinted by permission from Springer, N. Hu, W. Liu, L. Ding, Z. Wu, H. Yin, D. Huang, H. Li, L. Jin and H. Zheng, Removal of methylene blue from its aqueous solution by froth flotation: hydrophobic silica nanoparticle as a collector, J. Nanopart. Res., Copyright (2017).

Table 1 Results of reusability tests of SNPs (reproduced from ref. 52 with permission from Springer, copyright 2017). Reprinted by permission from Springer, N. Hu, W. Liu, L. Ding, Z. Wu, H. Yin, D. Huang, H. Li, L. Jin and H. Zheng, Removal of methylene blue from its aqueous solution by froth flotation: hydrophobic silica nanoparticle as a collector, J. Nanopart. Res., Copyright (2017)

\begin{tabular}{llllll}
\hline & 1 cycle & 2 cycles & 3 cycles & 4 cycles & 5 cycles \\
\hline$R_{\mathrm{MB}}(\%)$ & $91.1 \pm 4.6$ & $89.4 \pm 4.5$ & $88.3 \pm 4.4$ & $87.5 \pm 4.4$ & $85.9 \pm 4.3$ \\
$R_{\mathrm{SNPs}}(\%)$ & $93.9 \pm 4.7$ & $93.6 \pm 4.7$ & $93.3 \pm 4.7$ & $93.4 \pm 4.7$ & $93.1 \pm 4.7$ \\
$D(\%)$ & $94.3 \pm 4.7$ & $94.0 \pm 4.7$ & $93.5 \pm 4.7$ & $93.1 \pm 4.7$ & $92.5 \pm 4.6$
\end{tabular}

micronutrient for humans, animals and some plants. However, it may generate deposits during the recycling of high quality magnesia products from Saline Lake resources because it can be readily absorbed by magnesium hydroxide; this decreases the efficiency of recycling of high quality magnesia products from brine and boron in waste water, which is also poisonous to the environment. 88.69\% boron removal efficiency from Da Qaidam brine was obtained when Bai et al. adopted sodium dodecyl benzene sulfonate (SDBS) and D-mannitol as collectors while applying optimized flotation conditions. The removal mechanism is clearly depicted in Fig. 6. Firstly, borate can be formed in alkaline solution by interacting with hydroxide ion:

$$
\mathrm{B}(\mathrm{OH})_{3}+\mathrm{OH}^{-} \rightleftharpoons \mathrm{B}(\mathrm{OH})_{4}^{-}
$$

Afterwards, due to its oxophilic character, $\mathrm{B}(\mathrm{OH})_{4}{ }^{-}$can form stable complexes with D-mannitol (as shown in Fig. 6a); then, the negatively charged complexes can be readily absorbed by SDBS due to its electron-acceptor sulfo groups (as shown in Fig. 6b). Finally, the hydrophobic boric complexes can attach to the rising bubbles and reach the top of the flotation cell (as shown in Fig. 6c). ${ }^{56}$ Briefly speaking, ion flotation can efficiently remove organic and biological pollutants using various types of surfactants as collectors, and the mechanisms of interaction between the target ions and used surfactants vary based on the surfactant and target ions.

Reprinted from M. Groß, M. Tupinamba Lima, M. Uhlig, A. Ebraheme, O. Roeber, B. Olschewski, R. von Klitzing, R. Schomäcker and M. Schwarze, Biopolymers for dye removal via foam separation, Sep. Purif. Technol., 2017, 188, 451-457, Copyright (2017), with permission from Elsevier.

In addition to the above studies, ion flotation has been applied to other target contaminants. However, considering the length of the present article, additional studies on wastewater treatment via ion flotation are summarized in Table 2.

As a promising technology for wastewater treatment, ion floatation has attracted increasing attention due to its low energy requirements, rapid operation, small space requirements, low residual concentration, relatively low cost, etc. However, it also has many disadvantages, such as secondary pollution caused by chemical synthetic surfactants, large consumption of biosurfactants, high cost of nanoparticle surfactants, etc. However, to further promote the practical application of ion flotation in wastewater treatment, more work should be undertaken to develop eco-friendly and highefficiency surfactants. Moreover, recycled surfactants will be very popular due to their low cost and environmental benignity.

\section{Recovery of precious metals}

Precious metals mainly refer to 8 metal elements, such as gold, silver and platinum, which have beautiful colors and are not susceptible to chemical reactions under normal conditions. Precious metal resources are scarce and non-renewable; thus, arbitrary disposal not only causes waste of resources but also environmental pollution. Therefore, the recovery, purification 

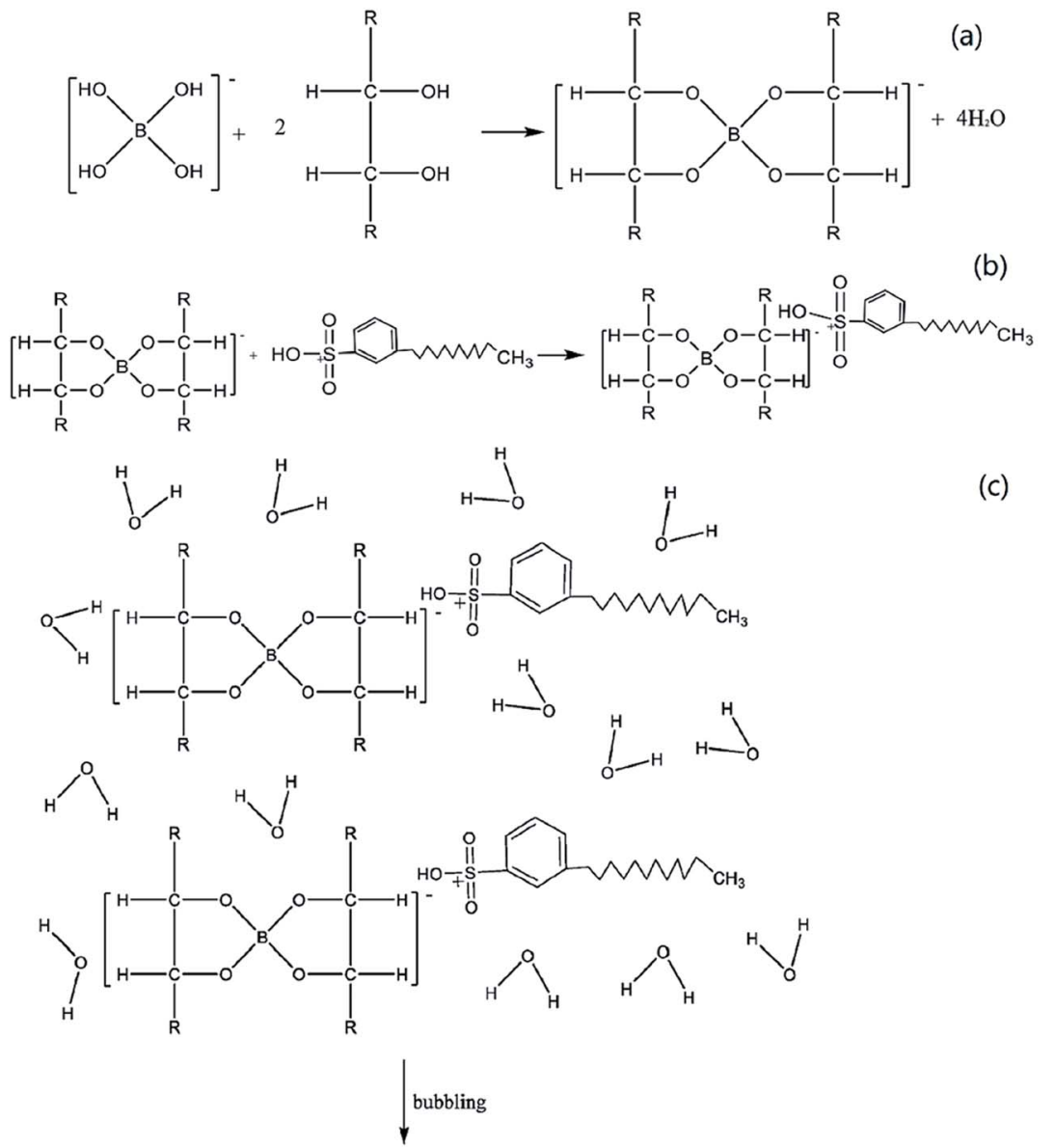

(c)

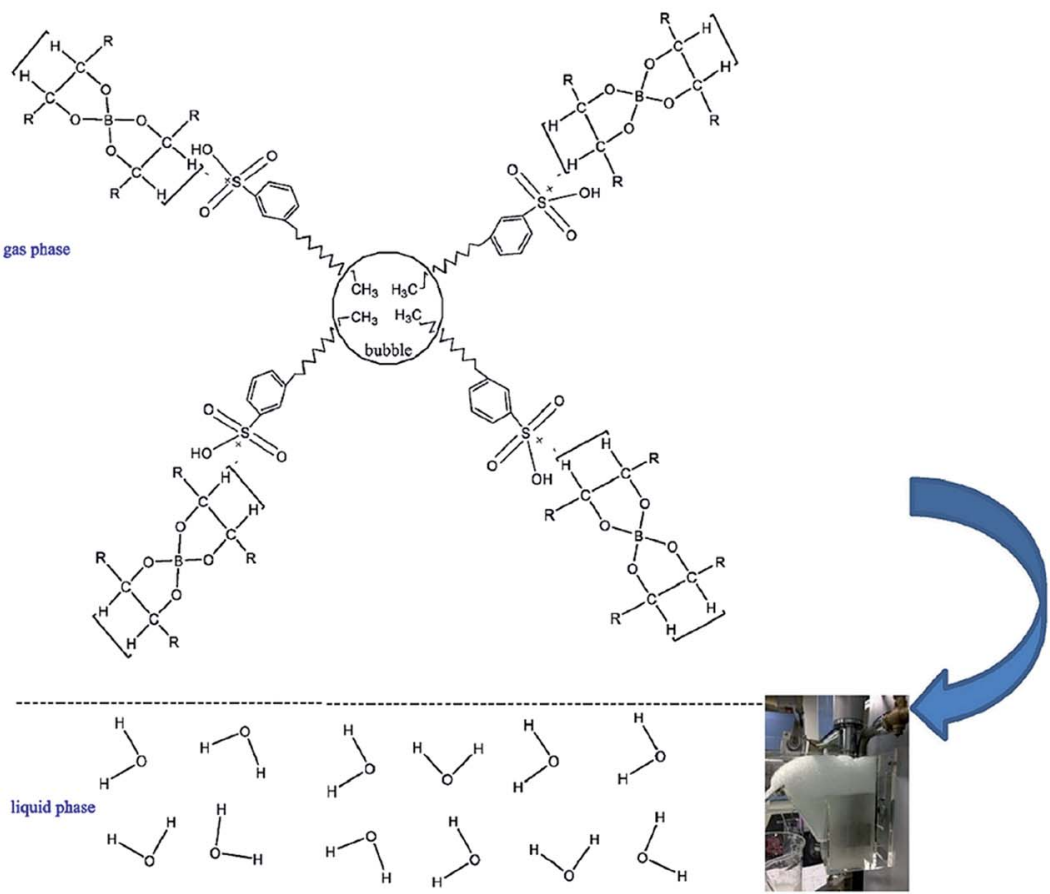

Fig. 6 The mechanism of boron removal. Adapted from ref. 56 with permission from Elsevier, Copyright 2018. Reprinted from C. Bai, M. Guo, Z. Liu, Z. Wu and Q. Li, A novel method for removal of boron from aqueous solution using sodium dodecyl benzene sulfonate and D-mannitol as the collector, Desalination, 2018, 431, 47-55, Copyright (2018), with permission from Elsevier. Reprinted with permission by Elsevier. ${ }^{56}$ 
Table 2 Research results of wastewater treatment via ion flotation

\begin{tabular}{|c|c|c|c|c|}
\hline Target contaminant & Collector & Experimental conditions & Removal (\%) & Ref. \\
\hline $\mathrm{Cu}(\mathrm{II})$ & EHDABr & 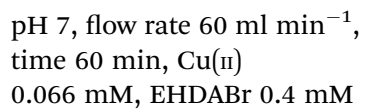 & 99 & 57 \\
\hline $\mathrm{Cu}(\mathrm{II})$ & Xanthates & $\begin{array}{l}\mathrm{pH} 2.5 \text { to } 5.5,10 \% \text { excess of } \\
\text { xanthate, airflow rate } 100 \\
\mathrm{~cm}^{3} \mathrm{~min}^{-1}\end{array}$ & $100 \%$ & 58 \\
\hline $\mathrm{Cu}(\mathrm{II})$ & $\begin{array}{l}\text { Anti and syn 2-hydroxy-3,5- } \\
\text { di-tert-butyl-benzaldoxime }\end{array}$ & $\begin{array}{l}\mathrm{pH} 8.5 \text { to } 9.5, \mathrm{Cu}(\mathrm{II}) \\
200 \mathrm{mg} \mathrm{L}^{-1}, \text { molar ratio of } \\
\text { surfactant } / \text { metal } 1: 2\end{array}$ & 100 & 59 \\
\hline $\mathrm{Cu}(\mathrm{II})$ & $\begin{array}{l}\text { Dry baker's yeast and } \\
\text { cetylpyridinium bromide } \\
\text { (CPB) }\end{array}$ & $\begin{array}{l}\mathrm{pH} 4.5 \text {, biosorbent } 0.5 \% \mathrm{w} / \mathrm{v} \text {, } \\
10 \mathrm{~min}, \mathrm{CPB} 0.01 \mathrm{M} \text {, molar } \\
\text { ratio } \mathrm{CPB} / \mathrm{Cu}(\mathrm{II}) 1: 2\end{array}$ & 97.09 & 60 \\
\hline $\mathrm{Cu}(\mathrm{II})$ & $\begin{array}{l}\text { Sodium } \\
\text { diethyldithiocarbamate } \\
\text { (DEDTK) }\end{array}$ & $\begin{array}{l}\mathrm{pH} 3, \mathrm{Cu}(\mathrm{II}) 50 \mathrm{mg} \mathrm{L}^{-1}, \\
\text { airflow rate } 1.8 \mathrm{~L} \mathrm{~min}^{-1}, \\
\text { foaming agent } 39.6 \mathrm{~g} \mathrm{~m}^{-3}\end{array}$ & 96.4 & 61 \\
\hline $\mathrm{Cu}(\mathrm{II})$ & Silica nanoparticles (SNP) & $\begin{array}{l}\mathrm{pH} 6.0, \mathrm{Cu}(\mathrm{II}) 15 \mathrm{mg} \mathrm{L}{ }^{-1}, \mathrm{SNP} \\
90 \mathrm{mg} \mathrm{L} \mathrm{L}^{-1}, \mathrm{CTAB} 35 \mathrm{mg} \mathrm{L}^{-1}, \\
\text { flotation column height } 750 \\
\mathrm{~mm}\end{array}$ & $94.5 \pm 4.7$ & 62 \\
\hline $\mathrm{Pb}$ (II) & SDS and barley husk & $\begin{array}{l}\mathrm{pH} 8, \mathrm{~Pb}(\mathrm{II}) 50 \mathrm{mg} \mathrm{L}^{-1} \text {, barley } \\
\text { husk } 20 \mathrm{mg} \mathrm{L}^{-1} \text {, SDS } \\
25 \mathrm{mg} \mathrm{L}^{-1} \text {, airflow rate } 1 \\
\mathrm{~L} \mathrm{~min}^{-1}\end{array}$ & 95 & 9 \\
\hline $\mathrm{Pb}$ (II) & SDS & $\begin{array}{l}\mathrm{pH} 8, \mathrm{~Pb}(\mathrm{II}) 50 \mathrm{mg} \mathrm{L}^{-1}, \mathrm{SDS} \\
25 \mathrm{mg} \mathrm{L}^{-1} \text {, airflow rate } 1 \\
\mathrm{~L} \mathrm{~min}^{-1}\end{array}$ & 85 & 9 \\
\hline $\mathrm{Pb}$ (II) & Sodium lauryl sulfate & $\begin{array}{l}\mathrm{pH} 8.2, \text { molar ratio of } \\
\text { surfactant/metal } 2\end{array}$ & 97 & 63 \\
\hline $\mathrm{Cd}(\mathrm{II})$ & $\begin{array}{l}\text { Sodium trideceth-4 } \\
\text { carboxylate (AEC) }\end{array}$ & $\begin{array}{l}\mathrm{pH} 7.5 \text {, AEC } 7.5 \mathrm{mM} \text {, molar } \\
\text { ratio of surfactant/metal } 10\end{array}$ & 99.8 & 64 \\
\hline $\mathrm{Cd}(\mathrm{II})$ & $\begin{array}{l}\text { Potassium ethyl xanthate } \\
\text { (KEtX) }\end{array}$ & $\begin{array}{l}\mathrm{pH} 6.2, \mathrm{Cd} \text { (II) } 0.5 \mathrm{mM}, \mathrm{KEtX} / \\
\mathrm{Cd}(\mathrm{II}) \text { molar ratio } 3,30 \mathrm{~min}\end{array}$ & 64 & 65 \\
\hline Cd(II) & $\begin{array}{l}\text { KEtX and HDTMA } \\
\text { KEtX and SDS }\end{array}$ & $\begin{array}{l}\text { pH 6.2, Cd(II) } 0.5 \mathrm{mM} \text {, KEtX/ } \\
\text { Cd(II) molar ratio } 3 \text {, collector } \\
0.25 \mathrm{mM}, 30 \mathrm{~min}\end{array}$ & $\begin{array}{l}99 \\
93\end{array}$ & 65 \\
\hline $\mathrm{Zn}$ (II) & EHDABr & 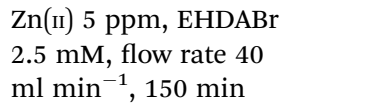 & 95.98 & 66 \\
\hline $\mathrm{Co}$ (II) & $\begin{array}{l}\text { EDTA and cetylpyridinium } \\
\text { chloride (CPyCl) }\end{array}$ & Co(II) : EDTA : CPyCl $1: 1: 4$ & 99 & 28 \\
\hline $\mathrm{U}(\mathrm{vI})$ & $\begin{array}{l}\text { Cetyl trimethylammonium } \\
\text { bromide }\end{array}$ & 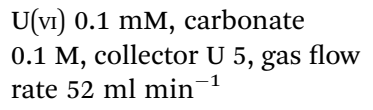 & 100 & 67 \\
\hline Ge(IV) & Pyrogallol and DA & $\begin{array}{l}\mathrm{pH} 4, \text { metal } \\
\text { ions }: \text { pyrogallol }: \mathrm{DA} \\
1: 3: 3\end{array}$ & 100 & 14 \\
\hline $\mathrm{Cr}_{2} \mathrm{O}_{7}^{2-}$ & EHDABr & $\begin{array}{l}\text { pH } 5.2 \text {, air rate } 1600 \\
\text { ml min }{ }^{-1} \text {, retention time } \\
150 \mathrm{~min}\end{array}$ & 90 & 68 \\
\hline $\mathrm{Cr}_{2} \mathrm{O}_{7}^{2-}$ & Rhamnolipid (RL) & $\begin{array}{l}\mathrm{Cr}(\mathrm{vI}) 40 \mathrm{ppm}, \mathrm{pH} 8, \text { airflow } \\
\text { rate } 50 \mathrm{ml} \mathrm{min}^{-1}, \mathrm{RL} / \mathrm{Cr} \\
\text { molar ratio } 0.01, \mathrm{Fe} / \mathrm{Cr} \text { molar } \\
\text { ratio } 3\end{array}$ & 95 & 69 \\
\hline $\mathrm{Ni}(\mathrm{II})$ & R. opacus & pH $5, \mathrm{Ni}(\mathrm{II}) 5 \mathrm{mg} \mathrm{L}^{-1}, \mathrm{Al}$ & 90 & 70 \\
\hline $\operatorname{Al}(\mathrm{III})$ & & $\begin{array}{l}50 \mathrm{mg} \mathrm{L}^{-1}, \text { R. opacus } 2 \mathrm{~g} \mathrm{~L}^{-1} \\
15 \mathrm{~min}\end{array}$ & 93 & \\
\hline $\mathrm{Pb}(\mathrm{II})$ & Sodium alginate and SDBS & pH 5.35, Pb(II) 0.4 mM, Cu(II) & 99 & 71 \\
\hline $\mathrm{Cu}(\mathrm{II})$ & & $\begin{array}{l}1.5 \mathrm{mM} \text {, calcium chloride } \\
4 \mathrm{wt} \% \text {, flow rate } 120 \\
\mathrm{~cm}^{3} \mathrm{~min}^{-1}\end{array}$ & 92 & \\
\hline $\begin{array}{l}\mathrm{Zn}(\text { II) } \\
\mathrm{Cd}(\mathrm{II})\end{array}$ & SDBS & $\begin{array}{l}\mathrm{Cd}(\mathrm{II}) / \mathrm{Zn} \text { (II) } 0.01 \mathrm{mM} \text {, } \\
\text { collector } 0.1 \mathrm{mM} \text {, surfactant } \\
0.2 \mathrm{mM}, 60 \mathrm{~min}\end{array}$ & $\begin{array}{l}90 \\
95.2\end{array}$ & 72 \\
\hline
\end{tabular}


Table 2 (Contd.)

\begin{tabular}{|c|c|c|c|c|}
\hline $\begin{array}{l}\operatorname{As}(\mathrm{v}) \\
\operatorname{Mo}(\mathrm{vI})\end{array}$ & SDS & $\begin{array}{l}\text { pH 4.0, SDS } 54.13 \mathrm{mg} \mathrm{L}^{-1}, \\
\text { Fe(III) } 134.89 \mathrm{mg} \mathrm{L}^{-1}, \mathrm{Mo}(\mathrm{VI})^{-1} \\
48 \mathrm{mg} \mathrm{L}^{-1}, \operatorname{As}(\mathrm{v}) 60 \mathrm{mg} \mathrm{L}^{-1}\end{array}$ & $\begin{array}{l}99.4 \\
99.9\end{array}$ & 73 \\
\hline $\begin{array}{l}\mathrm{Ca}(\mathrm{II}) \\
\mathrm{SO}_{4}{ }^{2-}\end{array}$ & $\begin{array}{l}\text { Calcium aluminate } \\
\text { compound }\end{array}$ & $\begin{array}{l}\mathrm{pH} \text { above } 11.5, \mathrm{CaO} 0.75 \mathrm{~g} \\
\mathrm{~L}^{-1}, \text { monocalcium } \\
\text { aluminate }(\mathrm{C} 70) 2 \mathrm{~g} \mathrm{~L}^{-1} \\
\text { reaction time } 6 \mathrm{~h}\end{array}$ & $\begin{array}{l}80 \\
90\end{array}$ & 74 \\
\hline $\begin{array}{l}\mathrm{Pb} \text { (II) } \\
\mathrm{Cu}(\mathrm{II}) \\
\mathrm{Cd}(\mathrm{II})\end{array}$ & Tea saponin & $\begin{array}{l}\mathrm{pH} 6 \text {, tea saponin to metal } \\
\text { ratio } 3: 1\end{array}$ & $\begin{array}{l}89.95 \\
81.13 \\
71.17\end{array}$ & 76 \\
\hline
\end{tabular}

and reuse of precious metals is conducive to the construction of ecological civilizations and sustainable development.

A pilot scale field trial of recovering gold cyanide anions from heap leaching liquor via ion flotation was undertaken with the aid of cetyltrimethyl ammonium bromide (CTAB) as the collector. Almost $100 \%$ of the gold could be recycled, and the recyclability of the collector was about $80 \%$ after 13 reagent recycle stages. ${ }^{78}$ Reyes et al. investigated the recovery of silver in spent diluted fixer through ion flotation using a column. A recovery of $97 \%$ could be obtained using $0.06 \mathrm{~g} \mathrm{~L}^{-1}$ of sodium isopropyl xanthate (SIX) and $0.04 \mathrm{~g} \mathrm{~L}^{-1}$ of frother. Additionally, controlling the $\mathrm{pH}$ at 6 helped improve the silver recovery. ${ }^{79}$ Meanwhile, silver recovery from dilute aqueous solutions containing thiosulphates by ion flotation was also proved to be feasible. A high recovery of silver (almost $100 \%$ ) could be obtained using dodecylamine as the collector together with ethanol (0.5\%) as the frother (as shown in Fig. 7). ${ }^{80}$

As mentioned above, ion flotation can be used to recover multiple precious metal ions or their cyanide complexes. An experiment of ion flotation on an aqueous solution of gold and silver cyanide anions was conducted with cetyltrimethylammonium bromide as the collector. Almost 100\% gold recovery could be obtained, and cetyltrimethylammonium bromide exhibited significant selectivity for gold over silver. ${ }^{81}$ The recovery of cationic complexes of rhodium and palladium via ion flotation was investigated using sodium dodecyl benzenesulfonate (SDBS) as the surfactant; it was noted that the cationic complexes of rhodium(III) and palladium(II) can be floated with SDBS. Otherwise, two ion flotation procedures were proposed which were rapid, simple and did not require expensive reagents or apparatus to obtain satisfactory separation of binary mixtures of $\mathrm{Rh}(\mathrm{III}), \mathrm{Pd}(\mathrm{II})$ and $\mathrm{Pt}\left(\mathrm{iv}\right.$ ) (as shown in Fig. 8). ${ }^{13}$ $\mathrm{Au}(\mathrm{III}), \mathrm{Ir}(\mathrm{III}), \mathrm{Pd}(\mathrm{II})$ and $\mathrm{Pt}(\mathrm{iv})$ could also be recovered by ion flotation when cationic collectors such as pentadecyl trimethyl ammonium bromide (PTMAB) and hexadecyl tripropyl ammonium bromide (HTPAB) were used. The recoveries of each metal were $99.9 \%, 99.8 \%, 99.45$ and $99.7 \%$, respectively, when floated under optimum conditions. The condensed foam volume was found to be less than $0.5 \mathrm{ml}$; thus, an enrichment of 200 -fold could be obtained, which shows that ion flotation can be an effective method for precious metals recovery. ${ }^{82}$

In summary, ion flotation exhibits great advantages over other technologies in recovering precious metals due to its simplicity, ease of operation, low cost, etc. However, most surfactants used for recovering precious metals have low separation indices. Meanwhile, the surfactants used also bring great environmental hazards, which restricts their industrial application. Therefore, environmentally friendly surfactants with

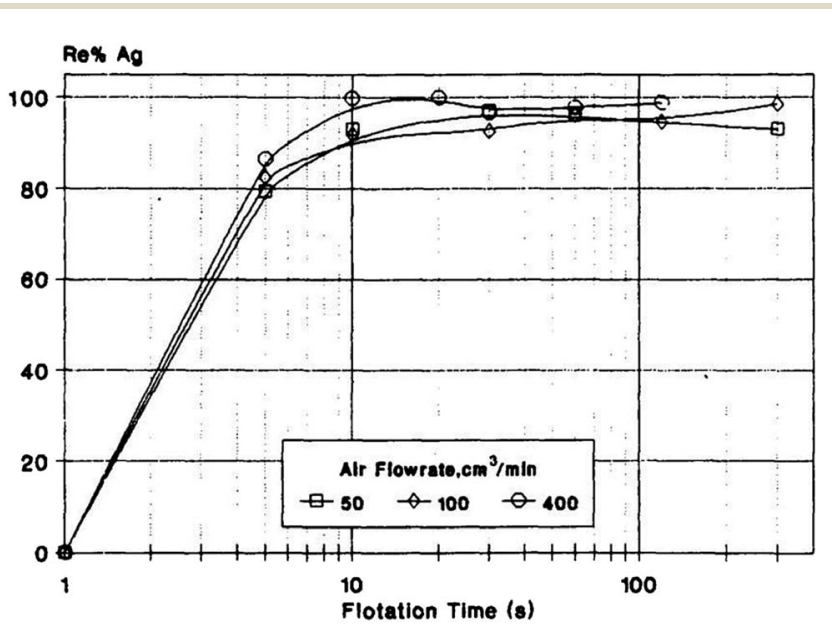

Fig. 7 Effects of flotation time and air flowrate on $R_{\text {Ag }}$. Reproduced from ref. 80 with permission from Elsevier, Copyright 1995. Reprinted from A. I. Zouboulis, Silver recovery from aqueous streams using ion flotation, Miner. Eng., 8, 1477-1488, Copyright (1995), with permission from Elsevier. 


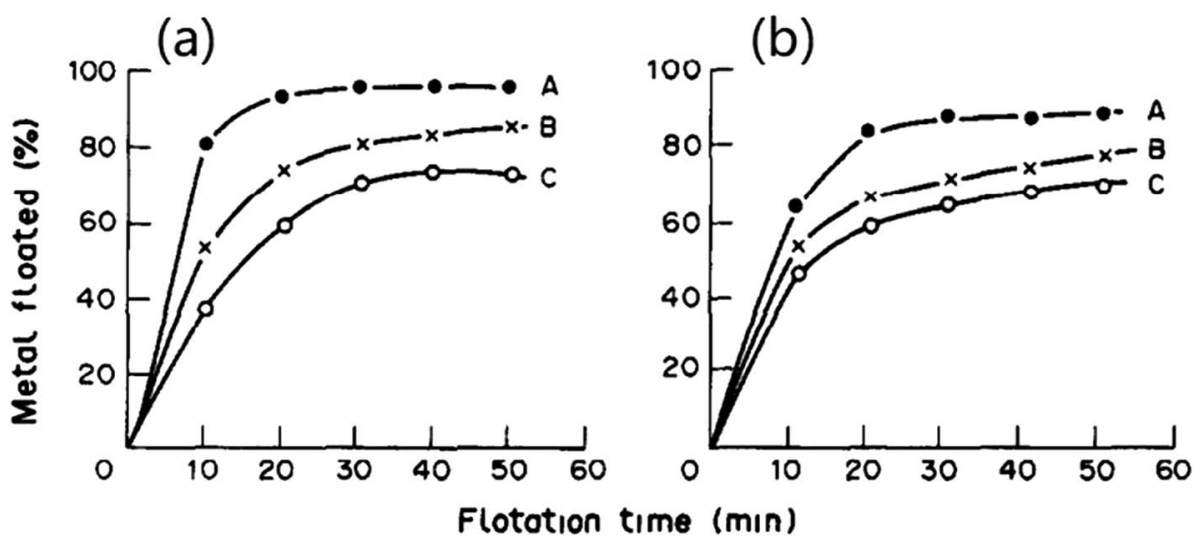

Fig. 8 Effects of flotation time and surfactants on $R_{\mathrm{Rh}}(\mathrm{a}), R_{\mathrm{Pd}}(\mathrm{b})$ recovery: A SDBS, B SDS, C sodium lauryl sulfate (SLS). Reproduced from ref. 13 with permission from Elsevier, Copyright 1991. Reprinted from X. He, Ion flotation of rhodium(II) and palladium(॥) with anionic surfactants, Talanta, 38, 319-323, Copyright (1991), with permission from Elsevier.

high selectivity are urgently required to expand the practical application of ion flotation.

\section{Pre-concentration of rare-earth elements}

Rare-earth elements are widely used in semiconductors, electronic components, alloys, metallurgy, glass and ceramic manufacturing, special materials, and other industries; they have long been considered to be a strategic mineral resource. ${ }^{83}$ However, rare earth industries face the difficulty of separating certain elements from their sum. Ion flotation is a promising technology for ensuring production of concentrates containing $60 \%$ to $70 \%$ rare earth elements.

Rose $e t a l$. investigated conditions for concentrating yttrium from solution using $\alpha$-sulphonated fatty acids via ion flotation, and a maximum recovery of $99.5 \%$ was obtained under optimum conditions within 30 minutes; furthermore, they found that by increasing the $\mathrm{pH}$ to 8 , the extraction rate was 3 times faster with a smaller loss in extraction compared with flotation at $\mathrm{pH} 2.75 .^{84}$ Chirkst et al. found that as the $\mathrm{pH}$ increased, the distribution coefficients of yttrium(III), cerium(III) and europium(III) sharply increased to almost $100 \%$. The $\mathrm{pH}$ values of initial extraction of 4.5 for yttrium(III), 5.5 for cerium(III) and 6.2 for europium(III) indicate that these ions can be recovered and separated from each other by adjusting the $\mathrm{pH}$ value via ion flotation with sodium dodecyl sulfate serving as the collector (as shown in Fig. 9). The experimental results fitted well with the calculation of the instability constants of hydroxo complexes, solubility products of hydroxides, and Gibbs energies of formation of the specified compounds. ${ }^{85}$

Later, they found that cerium(III) and yttrium(III) could be concentrated individually from solutions of their salts at $\mathrm{pH} 4.5$ to 6 when sodium dodecyl sulfate was used as the surfactant; the experimental results were consistent with the calculated dissociation constant of dodecyl sulfuric acid obtained from experimental potentiometric titration curves of the solutions. ${ }^{15}$ Additionally, they used sodium dodecyl sulfate as a collector to concentrate lanthanides; upon addition of chloride ions in concentrations of 0.01 to $0.1 \mathrm{M}$, a decreasing tendency of the distribution coefficients and shifts of the maximum recovery to the region of higher $\mathrm{pH}$ values were noted. A maximum distribution coefficient could be obtained at a chloride concentration of $0.01 \mathrm{M}$, which helped to improve the separation efficiency (as shown in Table 3). ${ }^{16}$

The same phenomenon was also found when floating and concentrating $\mathrm{La}(\mathrm{III})$ from nitrate and nitrate-chloride solutions with dodecyl sulfate as the collector. However, the addition of chloride ions did not significantly improve the ion flotation of holmium(III); also, the distribution coefficient increased with the addition of chlorides and reached the maximum at a sodium chloride concentrate of $0.01 \mathrm{M}^{83}$.

Lobacheva et al. used sodium dodecyl sulfate as a collector to concentrate yttrium(III) and ytterbium(III) cations from diluted aqueous solutions in the presence of chloride ions via ion flotation. A decreasing tendency of the distribution coefficient $\left(K_{\text {distr. }}\right)$ and a shift of the maximum recovery to the range of lower $\mathrm{pH}$ values was found for ytterbium ion flotation with the addition of chloride. The $K_{\text {distr. }}$ of yttrium also decreased, while the $\mathrm{pH}$ of maximum recovery shifted to a higher value region. The maximum yttrium recovery (in the form of $\mathrm{Y}(\mathrm{OH})_{3}$ ) and separation coefficient could be obtained at a chloride concentration of $0.01 \mathrm{M}$ and $\mathrm{pH} 7.8 .^{86}$

Maximum recoveries of yttrium and cerium ions could be obtained at pH 5.5 and 7.0, respectively, by ion flotation according to their other research. This allows recovery and separation of cerium and yttrium cations from their salts in the course of processing of lean technogenic raw materials at properly chosen $\mathrm{pH}$ values. ${ }^{87}$

It can be concluded that ion flotation plays a critical role in concentrating and separating rare-earth elements due to its characteristics of low cost, small space requirement, energy saving, etc. Despite its numerous advantages, ion flotation also involves numerous difficulties; for example, when concentrating and separating multicomponent rare-earth elements, it is necessary to adjust the $\mathrm{pH}$ value more than once, which is 

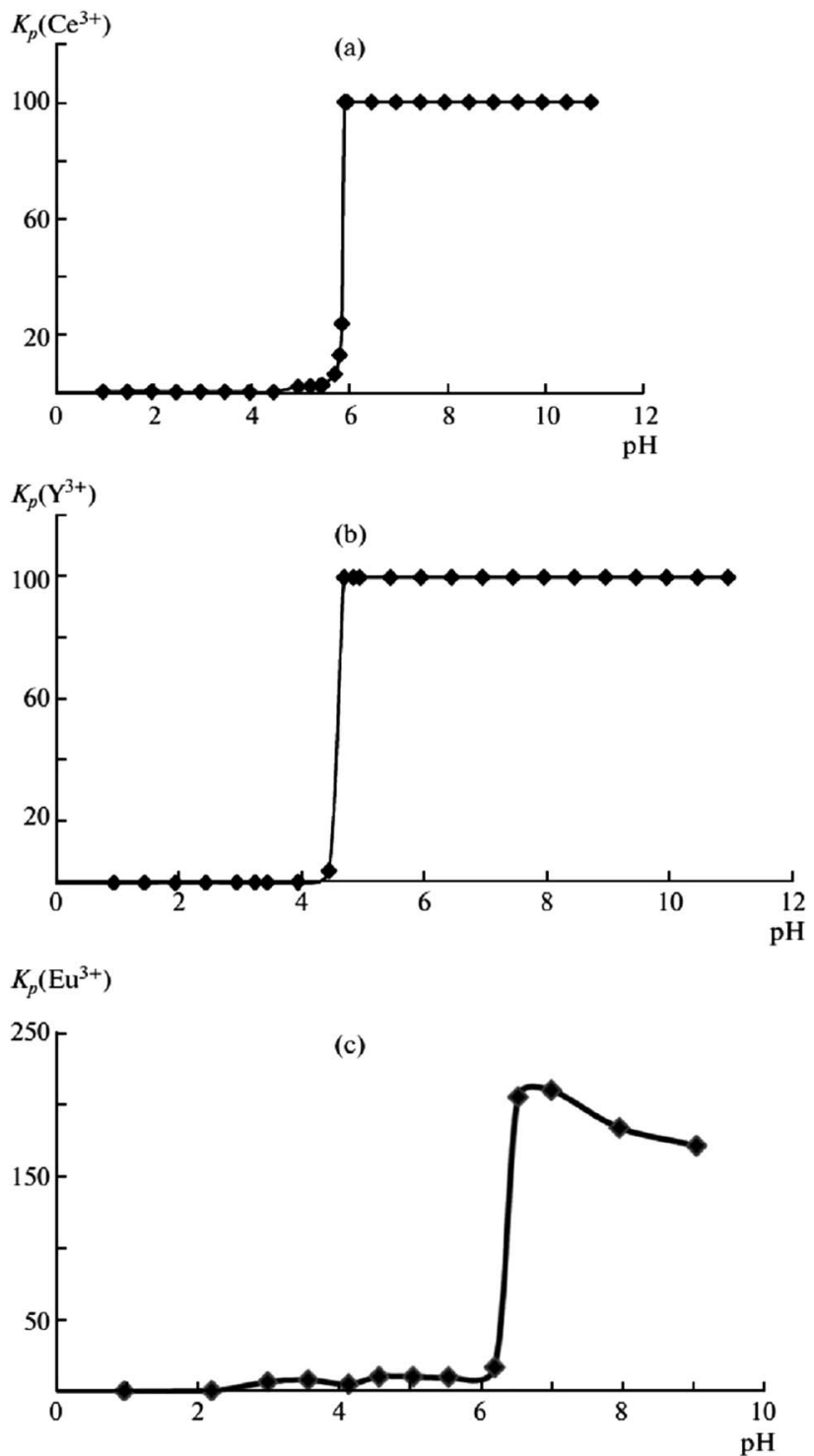

Fig. 9 Dependences of the distribution coefficients $K_{\text {distr }}$ of (a) $\mathrm{Ce}^{3+}$, (b) $\mathrm{Y}^{3+}$, and (c) $\mathrm{Eu}^{3+}$ ions on solution $\mathrm{pH}$. Reproduced from ref. 85 with permission from Springer, Copyright 2009. Reprinted by permission from Springer, D. E. Chirkst, O. L. Lobacheva, I. V. Berlinskii and M. I. Sulimova, Russ. J. Phys. Chem. A, The Thermodynamic Properties of Hydroxo Compounds and the Mechanism of Ion Flotation for Cerium, Europium, and Yttrium, Copyright (2009).

labor-intensive and time-consuming. In addition, the commonly used surfactants are harmful to the environment. Therefore, surfactants with biodegradability and selectivity should be considered as potential alternatives to the surfactants used at present.

\section{Selective separation of multicomponent ions}

As mentioned above, ion flotation is a promising separation technology for recovering or removing target ions. However, the solution to be treated usually contains more than one ion that needs to be recovered. Separation of one colligend of interest
Table 3 Separation coefficients of lanthanides under different conditions. (Reproduced from ref. 16 with permission from Springer, Copyright 2011.) Reprinted by permission from Springer, D. E. Chirkst, O. L. Lobacheva and N. V. Dzhevaga, Ion Flotation of Rare-Earth Metals with Sodium Dodecyl Sulfate, Russ. J. Appl. Chem., Copyright (2011)

\begin{tabular}{|c|c|c|c|c|c|c|}
\hline \multirow{2}{*}{$\begin{array}{l}\text { Separation } \\
\text { coefficient }\end{array}$} & \multicolumn{2}{|c|}{$c_{\mathrm{NaCl}}=0$} & \multicolumn{2}{|c|}{$c_{\mathrm{NaCl}}=0.01 \mathrm{M}$} & \multicolumn{2}{|c|}{$c_{\mathrm{NaCl}}=0.05 \mathrm{M}$} \\
\hline & $K_{\max }$ & $\mathrm{pH}$ & $K_{\max }$ & $\mathrm{pH}$ & $K_{\max }$ & $\mathrm{pH}$ \\
\hline$K_{\mathrm{Sm} / \mathrm{Ce}}$ & 5.53 & 6.70 & 7.54 & 7.00 & 1.51 & 7.60 \\
\hline$K_{\mathrm{Eu} / \mathrm{Ce}}$ & 13.78 & 6.70 & 41.52 & 7.00 & 1.39 & 7.65 \\
\hline$K_{\mathrm{Er} / \mathrm{Ce}}$ & 40.92 & 6.70 & 6.77 & 6.50 & 2.32 & 6.00 \\
\hline$K_{\mathrm{Ce} / \mathrm{Yb}}$ & 0.74 & 6.00 & 6.73 & 6.30 & 60.15 & 8.56 \\
\hline$K_{\mathrm{Ce} / \mathrm{Y}}$ & 0.54 & 4.50 & 9.80 & 6.50 & 32.41 & 8.56 \\
\hline$K_{\mathrm{Eu} / \mathrm{Sm}}$ & 1.10 & 6.00 & 14.60 & 6.30 & 0.92 & 7.40 \\
\hline$K_{\mathrm{Sm} / \mathrm{Er}}$ & 3.89 & 4.00 & 54.13 & 7.52 & 17.08 & 8.70 \\
\hline$K_{\mathrm{Sm} / \mathrm{Yb}}$ & 1.32 & 5.40 & 7.54 & 7.80 & 25.45 & 8.40 \\
\hline$K_{\mathrm{Sm} / \mathrm{Y}}$ & 1.60 & 3.50 & 25.73 & 6.60 & 13.72 & 8.40 \\
\hline$K_{\mathrm{Eu} / \mathrm{Er}}$ & 1.48 & 5.55 & 25.16 & 7.30 & 6.96 & 8.75 \\
\hline$K_{\mathrm{Eu} / \mathrm{Yb}}$ & 1.21 & 6.10 & 20.69 & 6.35 & 7.57 & 8.90 \\
\hline$K_{\mathrm{Eu} / \mathrm{Y}}$ & 0.92 & 4.60 & 99.45 & 6.70 & 3.49 & 8.40 \\
\hline$K_{\mathrm{Er} / \mathrm{Yb}}$ & 5.94 & 6.40 & 27.07 & 6.30 & 4.09 & 7.80 \\
\hline$K_{\mathrm{Y} / \mathrm{Er}}$ & 2.55 & 6.20 & 110.03 & 7.80 & 4.28 & 7.40 \\
\hline$K_{\mathrm{Y} / \mathrm{Yb}}$ & 3.04 & 7.00 & 49.73 & 7.80 & 8.62 & 7.80 \\
\hline
\end{tabular}

from other ions that may also be collected is quite necessary, either for economic reasons or for compliance with environmental restrictions on waste composition. Therefore, information on the selectivity between different ions is important for designing new ion flotation processes to recover valuable components from solutions and waste treatment. Moreover, it is advantageous to acquire a mechanistic understanding of the selective separation of one ion over others to assist in selecting appropriate collectors and conditions for a specific application. ${ }^{88}$

A great deal of research has been conducted on the selective separation of multicomponent ions by ion flotation, and satisfactory results have been acquired.

At the very beginning, the Gouy-Chapman diffuse layer theory was adopted to define the selective coefficient between two ions. According to this theory, a general discipline can be concluded that the selectivity of a colligend with a higher valence is usually greater than that of other ions with lower valence, which was verified by many studies. ${ }^{89,90}$

The selective adsorption coefficient between two ions in the Gouy-Chapman model is defined as

$$
\begin{gathered}
\alpha_{\mathrm{AB}}=\frac{(\Gamma / n)_{\mathrm{A}}}{(\Gamma / n)_{\mathrm{B}}} \\
=\frac{\int_{v_{0}}^{1} \frac{\left(v^{z_{\mathrm{A}}}-1\right) \mathrm{d} v}{v\left[\sum_{\mathrm{i}} n_{\mathrm{i}}\left(v^{z_{\mathrm{i}}}-1\right)\right]^{1 / 2}}}{\int_{v_{0}}^{1} \frac{\left(v^{z_{\mathrm{B}}}-1\right) \mathrm{d} v}{v\left[\sum_{\mathrm{i}} n_{\mathrm{i}}\left(v^{z_{\mathrm{i}}}-1\right)\right]^{1 / 2}}}
\end{gathered}
$$

where $(\Gamma / n)_{\mathrm{i}}$ is the distribution factor, $v=\exp (-\mathrm{e} \varphi / k T), \varphi$ is the potential, $z_{\mathrm{i}}$ is the valency of species $\mathrm{i}$, and $n_{\mathrm{i}}$ is the bulk concentration of ions of species i. 
There are two assumptions in the above theory; the first is that the dielectric constant is constant over the diffuse double layer and there is no polarization of ions, and the second is that the ions are points of charge with no radius so that there is no selectivity among ions with the same charge. Obviously, selectivity among ions of the same valency does in fact exist. Soon afterwards, Jorne and Rubin made some modifications on the basis of the Gouy-Chapman diffuse layer theory by introducing the difference in the distance of closest approach of ions with different sizes. The selective adsorption coefficient between two ions in the Jorne and Rubin model is defined as

$$
\alpha_{\mathrm{AB}}=\frac{\int_{v_{0}^{\prime \prime}}^{1} \frac{\left(v^{z_{\mathrm{A}}}-1\right) \mathrm{d} v}{v\left[\sum_{\mathrm{i}} n_{\mathrm{i}}\left(v^{z_{\mathrm{i}}}-1\right)\right]^{1 / 2}}}{\int_{v_{0}^{\prime \prime}}^{1} \frac{\left(v^{z_{\mathrm{B}}}-1\right) \mathrm{d} v}{v\left[\sum_{\mathrm{i}} n_{\mathrm{i}}\left(v^{z_{\mathrm{i}}}-1\right)\right]^{1 / 2}}+2\left(1 / n_{\mathrm{B}}\right)^{1 / 2}\left[\left(v_{0}^{\prime}\right)^{1 / 2}-\left(v_{0}^{\prime \prime}\right)^{1 / 2}\right]}
$$

Soon afterwards, they noted that experimental data for the separation of $\mathrm{Sr}^{2+}$ and $\mathrm{UO}^{2+}$ ions in the presence of monobutyl biphenyl sodium sulfonate as a collector fitted well with the above theory, which indicates that the selectivity of ion flotation relies not only on the charge but also on the size of the hydrated ion. ${ }^{18}$

Huang et al. experimentally studied the ion flotation of copper, cadmium and lead using sodium dodecylbenzene sulfonate on the basis of Jorne and Rubin's model. They found that the order of ion removal was $\mathrm{Cu}^{2+}<\mathrm{Cd}^{2+}<\mathrm{Pb}^{2+}$, which supports the fact that the selectivity depends on the charge and effective radii of the hydrated ion. ${ }^{91}$

An investigation of the ion flotation of the transition metal cations In(III), Cr(III), Fe(III), Cd(II), Mn(II), Co(II), Zn(II) and Ag(I) with sodium dodecylbenzene sulfonate and sodium dodecyl sulfonate as the collectors was conducted by Walkowiak; the selectivity sequence of $\mathrm{Ag}$ (I) $<\mathrm{Mn}$ (II) $<\mathrm{Zn}$ (II) $<\mathrm{Co}$ (II) $<\mathrm{Fe}$ (III) $<$ $\mathrm{Cr}($ III) $<$ In(III) was established, which verified that the preferential removal of certain metal ions is closely related to the ratio of ionic charge to ionic radius and the solubility products of the metal-collector compounds. Additionally, the result confirmed the selective foam fractional model proposed by Jorne and Robin, which was based on the Gouy-Chapman diffused double layer theory with the restriction that the closest approach to the surface is determined by the size of the hydrated ions. ${ }^{\mathbf{9 2}}$

Liu et al. developed two thermodynamically based theoretical models to predict the selectivity coefficients for $\mathrm{Ca}(\mathrm{II}): \mathrm{Cu}$ (II) and $\mathrm{Pb}$ (II) $: \mathrm{Cu}$ (II) in ion flotation with sodium dodecylsulfate (SDS) as the collector. Although the surface model predicted the right selectivity order, the selectivity coefficients did not match the experimentally measured selectivity. The selectivity coefficients estimated by the dehydration model were 1.55 and 2.07 for $\mathrm{Ca}(\mathrm{II}): \mathrm{Cu}$ (II) and $\mathrm{Pb}$ (II) $: \mathrm{Cu}$ (II), respectively, which agreed well with the experimentally measured values. ${ }^{\mathbf{8}}$

Liu et al. removed $\mathrm{Cd}(\mathrm{II}), \mathrm{Zn}(\mathrm{II})$ and $\mathrm{Cu}(\mathrm{II})$ from solution via ion flotation with rhamnolipid as a surfactant; they found that ions with larger crystalline radii preferentially reacted with the surfactant. ${ }^{93-95}$ The ratios of the ionic radii for the competitive systems were $1.03,1.28$ and 1.32 for $\mathrm{Zn} / \mathrm{Cu}, \mathrm{Cd} / \mathrm{Zn}$ and $\mathrm{Cd} / \mathrm{Cu}$, respectively. As shown in Fig. 10, the selectivity coefficient of Cd over Zn, SCd Zn, was determined to be 1.61 , with $R^{2}=0.9854$ (as shown in Fig. 10a); the selectivity coefficient of $\mathrm{Cd}$ over $\mathrm{Cu}$, SCd Cu, was determined to be 3.05, with a coefficient of determination, $R^{2}$, of 0.9593 (as shown in Fig. 10b); and the selectivity coefficient of $\mathrm{Zn}$ over $\mathrm{Cu}, \mathrm{SZn} \mathrm{Cu}$, was determined to be 1.677, with $R^{2}=0.9672$ (as shown in Fig. 10c). The obtained selectivity coefficient values were in accordance with the ratios of the ionic radii, which suggests that the selectivity sequence of these metals in ion flotation with rhamnolipid as the collector is $\mathrm{Cd}($ II $)>\mathrm{Zn}(\mathrm{II})>\mathrm{Cu}\left(\right.$ II).$^{96}$
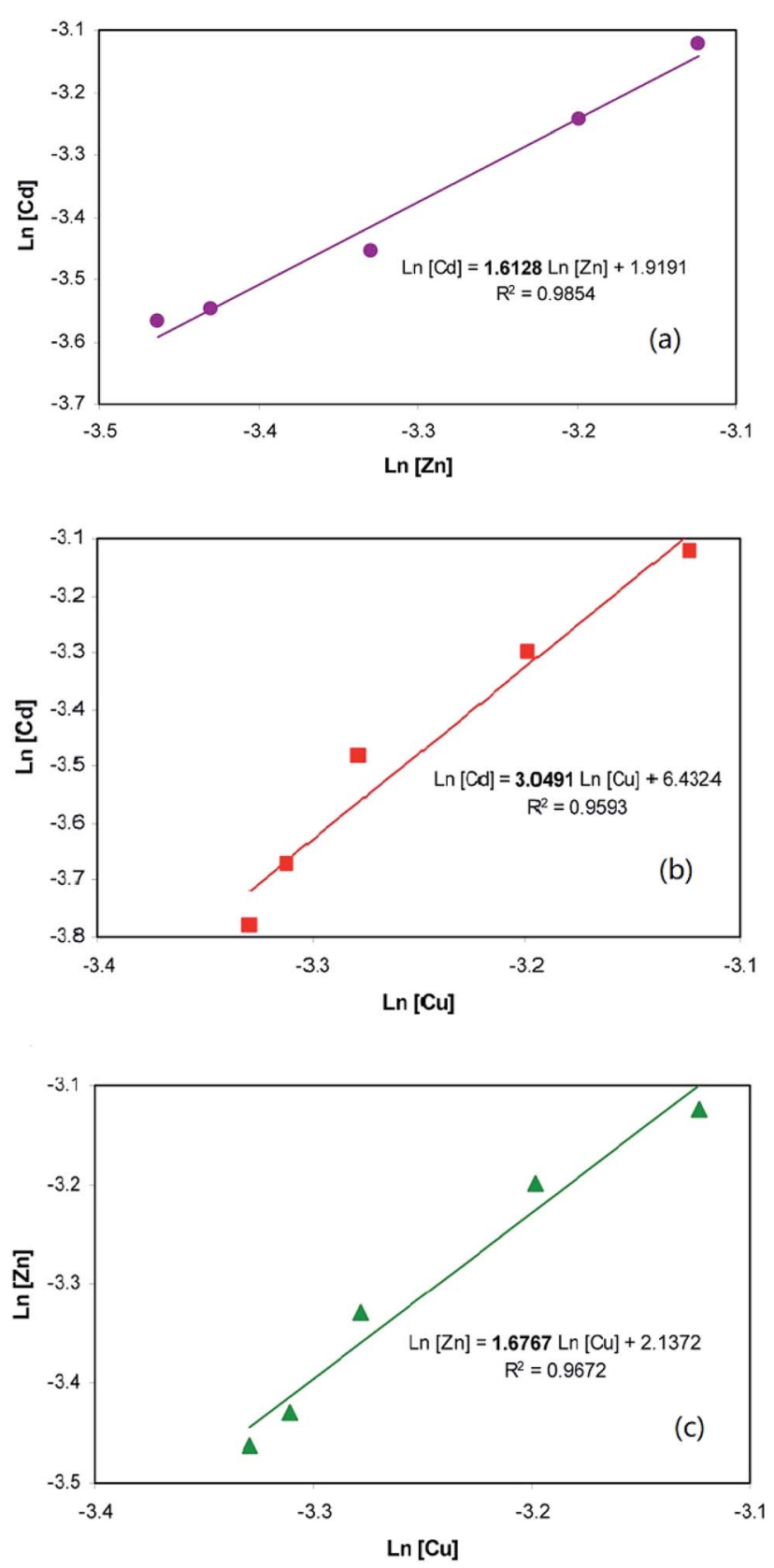

Fig. 10 Ion flotation selectivity coefficient determination: $\mathrm{Cd}$ and $\mathrm{Zn}$ (a), $\mathrm{Cd}$ and $\mathrm{Cu}$ (b), Zn and $\mathrm{Cu}$ (c). Adapted from ref. 96 with permission. Copyright 2013 American Chemical Society. 
Furthermore, Chirkst et al. discovered that the distribution coefficients of yttrium(III) and cerium(III) sharply increased to almost $100 \%$ at $\mathrm{pH} 4.5$ and 6 , respectively; therefore, recovery of yttrium(III) began at $\mathrm{pH} 4.5$ and recovery of cerium(III) began at $\mathrm{pH}$ 6. Thus, a general conclusion can be drawn that selective recovery of REMs can be obtained by varying the $\mathrm{pH}$ value. Additionally, they noted that the maximum yttrium recovery (in the hydrolysate form of $\mathrm{Y}(\mathrm{OH})_{3}$ ) and separation coefficient from ytterbium could be obtained at a chloride concentration of $0.01 \mathrm{M}$ and $\mathrm{pH}$ 7.8. It can be concluded that $\mathrm{pH}$ and hydrolysis also contribute to the selectivity of multicomponent ions.

The above results indicate that the selectivity of multicomponent ions is closely related to the valence, crystalline radii, and hydrated radii of the metal ions, the ratio of ionic charge to ionic radius, $\mathrm{pH}$, and hydrolysis together with the solubility products of the metal-collector compounds. Therefore, the selective separation of multicomponent ions can be easily accomplished with proper collectors, and accurate models should also be developed and established to predict the selectivity of different ions in future work.

Adapted with permission from A. Bodagh, H. Khoshdast, $\mathrm{H}$. Sharafi, H. S. Zahiri and K. A. Noghabi, Removal of Cadmium(II) from Aqueous Solution by Ion Flotation Using Rhamnolipid Biosurfactant as an Ion Collector, Ind. Eng. Chem. Res., 52, 39103917. Copyright (2013) American Chemical Society.

\section{Summary and outlook}

Currently, ion flotation, a promising separation technology, is widely used in the fields of wastewater treatment, mineral beneficiation, such as rare precious metal recovery, and hydrometallurgy, such as pre-concentrating of rare earth elements and selective separation of multicomponent ions. This technology has been widely recognized by the public due to its simplicity, rapidity, economy, good separation yields, and suitability for a variety of target ions at various levels.

Much progress has been achieved in the application of ion flotation. Biosurfactants were developed to overcome secondary pollution due to chemical surfactants. Recently, in order to conquer the problem of large consumption of surfactants, nanoparticle collectors were introduced into ion flotation. Moreover, many novel flotation machines have been developed simultaneously, such as a cyclonic state micro-bubble flotation column $^{47}$ and a modified Jameson cell. ${ }^{97}$ However, numerous challenges remain to be overcome. Among these, large consumption or high cost of collectors, secondary pollution from chemicals used in ion flotation and low selectivity among ions are the main factors that limit its practical application. In addition, more research should be pursued to develop new, efficient collectors which have the advantages of high efficiency, lower dosage, better selectivity, low cost and environmental friendliness.

\section{Conflicts of interest}

There are no conflicts to declare.

\section{Acknowledgements}

The authors gratefully acknowledge the financial support from the National Natural Science Foundation of China (project no. U1704252 and 51804275). Moreover, we also thank the China Postdoctoral Science Foundation (No. 2018M632811), Postdoctoral Fund of Henan Province (No. 174793), Scientific Research Start-up Project of Zhengzhou University (No. 32210793), Key scientific research project plan of Henan Colleges and Universities (No. 19A45001), and Modern Analysis and Computing Center in Zhengzhou University. The literature studies cited in this article are also acknowledged gratefully by the authors.

\section{References}

1 I. Langmuir and V. J. Schaefer, J. Am. Chem. Soc., 2002, 59, 2400-2414.

2 F. Sebba, Nature, 1959, 184, 1062-1063.

3 S. K. Nicol, K. P. Galvin and M. D. Engel, Miner. Eng., 1992, 5, 1259-1275.

4 E. A. Deliyanni, G. Z. Kyzas and K. A. Matis, J. Mol. Liq., 2017, 225, 260-264.

5 Ü. Yenial and G. Bulut, J. Mol. Liq., 2017, 241, 130-135.

6 J. J. da Rosa and J. Rubio, Miner. Eng., 2005, 18, 701-707.

7 E. Carissimi and J. Rubio, Int. J. Miner. Process., 2005, 75, 237-247.

8 J. Rubio, M. L. Souza and R. W. Smith, Miner. Eng., 2002, 15, 139-155.

9 A. A. Mohammed, S. E. Ebrahim and A. I. Alwared, Journal of Chemistry, 2013, 2013, 1-6.

10 S. E. Ghazy, S. M. Elmorsy and A. H. Ragab, J. Appl. Sci. Environ. Manage., 2010, 12, 75-82.

11 R. B. Grieves and G. A. Ettelt, AIChE J., 1967, 13, 1167-1171.

12 R. B. Grieves, T. E. Wilson and K. Y. Shih, AIChE J., 1965, 11, 820-824.

13 X. C. He, Talanta, 1991, 38, 319-323.

14 A. Hernández-Expósito, J. M. Chimenos, A. I. Fernández, O. Font, X. Querol, P. Coca and F. García Peña, Chem. Eng. J., 2006, 118, 69-75.

15 D. E. Chirkst, O. L. Lobacheva, I. V. Berlinskii and M. A. Sulimova, Russ. J. Appl. Chem., 2009, 82, 1370-1374.

16 D. E. Chirkst, O. L. Lobacheva and N. V. Dzhevaga, Russ. J. Appl. Chem., 2011, 84, 1476-1482.

17 Z. Bahri, B. Rezai and E. Kowsari, Miner. Eng., 2016, 86, 104113.

18 J. Jorné and E. Rubin, Sep. Sci., 1969, 4, 313-324.

19 B. Kawalec-Pietrenko and P. Rybarczyk, Chem. Pap., 2014, 68, 890-898.

20 J. S. Guest, S. J. Skerlos, J. L. Barnard, B. M Bruce, G. T. Daigger, H. Helene, S. J. Jackson, K. Karen, K. Linda and M. Linda, Environ. Sci. Technol., 2009, 43, 6126-6130.

21 T. Oki, S. Kanae and K. Musiake, Membrane, 2003, 28, 206214.

22 D. Zamboulis, E. N. Peleka, N. K. Lazaridis and K. A. Matis, J. Chem. Technol. Biotechnol., 2011, 86, 335-344. 
23 W. Peng, H. Li, Y. Liu and S. Song, J. Mol. Liq., 2017, 230, 496-504.

24 D. S. Patil, S. M. Chavan and J. U. K. Oubagaranadin, J. Environ. Chem. Eng., 2016, 4, 468-487.

25 V. Coman, B. Robotin and P. Ilea, Resour. Conserv. Recycl., 2013, 73, 229-238.

26 S. S. Ahluwalia and D. Goyal, Bioresour. Technol., 2007, 98, 2243-2257.

27 H. Polat and D. Erdogan, J. Hazard. Mater., 2007, 148, 267273.

28 M. A. Soliman, G. M. Rashad and M. R. Mahmoud, Radiochim. Acta, 2015, 103, DOI: 10.1515/ract-2015-2390.

29 A. Paraneeiswaran, S. K. Shukla, T. Subba Rao and K. Prashanth, Chemosphere, 2014, 95, 503-510.

30 V. K. Gupta, A. Shilpi and T. A. Saleh, J. Hazard. Mater., 2010, 185, 17-23.

31 B. A. Fowler, Toxicol. Appl. Pharmacol., 2009, 238, 294-300.

32 Z. Guixia, R. Xuemei, G. Xing, T. Xiaoli, L. Jiaxing, C. Changlun, H. Yuying and W. Xiangke, Dalton Trans., 2011, 40, 10945-10952.

33 G. Craioveanu, L. Stoica and C. Constantin, Sep. Sci. Technol., 2015, 50, 802-812.

34 W. Peng, G. Han, Y. Cao, K. Sun and S. Song, Colloids Surf., A, 2018, 556, 266-272.

35 W. Peng, H. Li, Y. Liu and S. Song, Appl. Surf. Sci., 2016, 364, 620-627.

36 M. H. Salmani, M. Davoodi, M. H. Ehrampoush, M. T. Ghaneian and M. H. Fallahzadah, Iran. J. Environ. Health Sci. Eng., 2013, 10, 16.

37 M. R. Mahmoud and N. K. Lazaridis, Sep. Sci. Technol., 2015, 50, 1421-1432.

38 F. S. Hoseinian, M. Irannajad and A. J. Nooshabadi, Int. J. Miner. Process., 2015, 143, 131-137.

39 A. Eivazihollagh, J. Tejera, I. Svanedal, H. Edlund, A. Blanco and M. Norgren, Ind. Eng. Chem. Res., 2017, 56, 10605-10614.

40 M. Doğutan Yenidünya, Sep. Sci. Technol., 2006, 41, 17411756.

41 Y.-C. Lee, P.-Y. Wang, S.-L. Lo and C. P. Huang, Sep. Purif. Technol., 2017, 173, 280-285.

42 A. Pruss, Water Sci. Technol., 2015, 71, 645-652.

43 J. Yan, Z. Wu, Y. Zhao and C. Jiang, Sep. Purif. Technol., 2011, 80, 300-305.

44 L. Zaleschi, M. S. Secula, C. Teodosiu, C. S. Stan and I. Cretescu, Water, Air, Soil Pollut., 2014, 225, DOI: 10.1007/ s11270-014-2101-z.

45 L. Zhang, B. Cao, D. Yao, R. Yu, C. Yu, H. Zhang and A. Yu, J. Sep. Sci., 2015, 38, 1733-1740.

46 L. Zhang, D. Yao, R. Yu, N. Li, H. Zhang and A. Yu, Anal. Methods, 2015, 7, 1977-1983.

47 X. Li, H. Xu, J. Liu, J. Zhang, J. Li and Z. Gui, Sep. Purif. Technol., 2016, 165, 101-106.

48 H. W. Mu, M. L. Granstrom, T. E. Wilson and L. K. Wang, Jawra Journal of the American Water Resources Association, 2010, 10, 283-294.

49 S. J. Choi and Y. H. Choi, Sep. Sci. Technol., 2006, 31, 21052116.
50 K. Shakir, A. F. Elkafrawy, H. F. Ghoneimy, S. G. Elrab Beheir and M. Refaat, Water Res., 2010, 44, 1449-1461.

51 M. Groß, M. Tupinamba Lima, M. Uhlig, A. Ebraheme, O. Roeber, B. Olschewski, R. von Klitzing, R. Schomäcker and M. Schwarze, Sep. Purif. Technol., 2017, 188, 451-457.

52 N. Hu, W. Liu, L. Ding, Z. Wu, H. Yin, D. Huang, H. Li, L. Jin and H. Zheng, J. Nanopart. Res., 2017, 19, DOI: 10.1007/ s11051-017-3762-5.

53 K. Sungpyo, E. Peter, J. N. Jensen, W. A Scott and D. S. Aga, Environ. Sci. Technol., 2005, 39, 5816-5823.

54 D. Li, M. Yang, J. Hu, L. Ren, Y. Zhang and K. Li, Environ. Toxicol. Chem., 2010, 27, 80-86.

55 T. Saitoh, K. Shibata, K. Fujimori and Y. Ohtani, Sep. Purif. Technol., 2017, 187, 76-83.

56 C. Bai, M. Guo, Z. Liu, Z. Wu and Q. Li, Desalination, 2018, 431, 47-55.

57 C. McDonald and A. Suleiman, Sep. Sci. Technol., 1979, 14, 219-225.

58 N. K. Lazaridis, E. N. Peleka, T. D. Karapantsios and K. A. Matis, Hydrometallurgy, 2004, 74, 149-156.

59 L. Stoica and I. Lacatusu, Int. J. Environ. Waste Manage., 2012, 9, 293.

60 L. Stoica, A.-M. Stanescu, C. Constantin, O. Oprea and G. Bacioiu, Water, Air, Soil Pollut., 2015, 226, DOI: 10.1007/ s11270-015-2533-0.

61 K. A. Strel'tsov and D. V. Abryutin, Russian Journal of NonFerrous Metals, 2010, 51, 85-88.

62 N. Hu, W. Liu, L. Jin, Y. Li, Z. Li, G. Liu, D. Huang, Z. Wu and H. Yin, Sep. Purif. Technol., 2017, 184, 257-263.

63 A. J. Rubin and W. L. Lapp, Anal. Chem., 1969, 41, 1133-1135. 64 J. Lu, Y. Li, S. Zhang and Y. Sun, J. Hazard. Mater., 2015, 286, 466-473.

65 M. R. Mahmoud, N. K. Lazaridis and K. A. Matis, Process Saf. Environ., 2015, 94, 203-211.

66 C. W. McDonald and O. A. Ogunkeye, Microchem. J., 1981, 26, 80-85.

67 K. Shakir, J. Appl. Chem. Biotechnol., 1973, 23, 339-347.

68 R. B. Grieves and S. M. Schwartz, J. Chem. Technol. Biotechnol., Biotechnol., 2010, 16, 14-17.

69 A. Salmani Abyaneh and M. H. Fazaelipoor, J. Environ. Manage., 2016, 165, 184-187.

70 J. E. B. Cayllahua and M. L. Torem, Desalination, 2011, 279, 195-200.

71 A. G. Corpuz, P. Pal, F. Banat and M. A. Haija, Sep. Purif. Technol., 2018, 202, 103-110.

72 U. Malgorzata, W. Wladyslaw, J. Youngchan, K. Jong Seung and R. A. Bartsch, Anal. Chem., 2003, 75, 2276-2279.

73 Y. Zhao, A. I. Zouboulis and K. A. Matis, Sep. Sci. Technol., 1996, 31, 769-785.

74 A. D. Guerrero-Flores, A. Uribe-Salas, G. I. Dávila-Pulido and J. M. Flores-Álvarez, Miner. Eng., 2018, 123, 28-34.

75 G. A. Stalidis, K. A. Matis and N. K. Lazaridis, Sep. Sci. Technol., 1989, 24, 97-109.

76 X. Z. Yuan, Y. T. Meng, G. M. Zeng, Y. Y. Fang and J. G. Shi, Colloids Surf., A, 2008, 317, 256-261. 
77 M. Taseidifar, F. Makavipour, R. M. Pashley and A. F. M. M. Rahman, Environmental Technology \& Innovation, 2017, 8, 182-190.

78 K. P. Galvin, M. D. Engel and S. K. Nicol, Int. J. Miner. Process., 1994, 42, 75-98.

79 M. Reyes, F. Patiño, R. Escudero, M. Pérez, M. U. Flores and I. Reyes, J. Mex. Chem. Soc., 2012, 56, 408-416.

80 A. I. Zouboulis, Miner. Eng., 1995, 8, 1477-1488.

81 P. K. Galvin, K. S. Nicol and G. A. Waters, Colloids Surf., 1992, 64, 21-33.

82 E. W. Berg and D. M. Downey, Anal. Chim. Acta, 1980, 120, 237-248.

83 D. E. Chirkst, O. L. Lobacheva and N. V. Dzhevaga, Russ. J. Appl. Chem., 2012, 85, 25-28.

84 M. W. Rose and F. Sebba, J. Chem. Technol. Biotechnol., Biotechnol., 2010, 19, 185-187.

85 D. E. Chirkst, O. L. Lobacheva, I. V. Berlinskii and M. I. Sulimova, Russ. J. Phys. Chem. A, 2009, 83, 2022-2027.

86 O. Lobacheva, N. Dzhevaga and A. Danilov, Journal of Ecological Engineering, 2016, 17, 38-42.
87 O. L. Lobacheva, I. V. Berlinskii and O. V. Cheremisina, Russ. J. Appl. Chem., 2015, 87, 1863-1867.

88 Z. Liu and F. M. Doyle, Colloids Surf., A, 2001, 178, 93-103.

89 K. Kubota and S. Hayashi, Can. J. Chem. Eng., 1977, 55, 286292.

90 C. Walling, E. E. Ruff and J. L. Thornton, J. Phys. Chem., 1957, 61, 486-490.

91 R. C. H. Huang and F. D. Talbot, Can. J. Chem. Eng., 1973, 51, 709-713.

92 W. Walkowiak, Sep. Sci. Technol., 1991, 26, 559-568.

93 Z. Liu and F. M. Doyle, Miner. Metall. Process., 2001, 18, 167171.

94 M. Ulewicz, W. Walkowiak and C. Kozłowski, Fizykochem. Probl. Mineralurgii, 2001, 35, 21-29.

95 Z. X. Yuan, T. Y. Meng, M. G. Zeng, Y. Y. Fang and G. J. Shi, Colloids Surf., A, 2008, 317, 256-261.

96 A. Bodagh, H. Khoshdast, H. Sharafi, H. Shahbani Zahiri and K. Akbari Noghabi, Ind. Eng. Chem. Res., 2013, 52, 3910-3917.

97 M. Santander, L. Valderrama, M. Guevara and J. Rubio, Miner. Eng., 2011, 24, 1010-1015. 